\title{
SURFACE AND SUBSURFACE KARST GEOMORPHOLOGY IN THE MURGE (APULIA, SOUTHERN ITALY)
}

\author{
POVRŠINSKA IN PODZEMNA GEOMORFOLOGIJA KRASA V \\ GRIČEVJU MURGE (APULIJA, J ITALIJA)
}

\author{
Mario PARISE ${ }^{1}$
}

\begin{abstract}
UDC 551.435.8(450.75)

Mario Parise: Surface and subsurface karst geomorphology in the Murge (Apulia, southern Italy)

The Murge (Apulia, southern Italy) is the main karst area in the central part of the region, extending from the inland plateau to the Adriatic coastline. Along this transect, a relief energy of a few hundred meters is reached. Even though such relief may seem small when compared to mountain karst areas, actually it is not for Apulia, a very flat carbonate region that acted as the foreland during the building up of the Apenninic Chain in Miocene time. Murge can be subdivided into two sectors: High Murge, the inland plateau, where remnants of an ancient tropical karst are still recognizable; and Low Murge, closer to the sea, with smoother karst morphologies and landforms. Here, some of the most remarkable underground karst systems of Apulia are located: the Castellana caves, a show cave that has been opened since 1939 to tourists (only a few months after the discovery), and the Pozzo Cucù karst system. Overall, the two systems (that are located few hundreds of meters apart) are more than 5,5 km long. In addition, many other karst caves are widespread in the territory, showing different typologies, from percolation shafts, to intrastratal caves, to tectonicallycontrolled caves, down to marine caves along the coastline. At the surface, other interesting morphological features related to karst may be observed, the main one being the Canale di Pirro polje, which cuts the SE Murge with an E-W strike, until its easternmost reach against the Murge fault line scarp. This latter is the main morphological feature intervening between the Murge plateau and the Adriatic plain. In this article the karst morphological features of Murge are depicted, putting together surface and underground data, in the effort to contribute to the recognition of the main phases of development of karst processes in the region.
\end{abstract}

Keywords: karst, geomorphology, caves, polje.
Izvleček

UDK 551.435.8(450.75)

Mario Parise: Površinska in podzemna geomorfologija krasa v gričevju Murge (Apulija, J Italija)

Gričevje Murge (Apulia, južna Italija) je pomembno kraško območje v osrednjem delu Apulije. Razteza se od notranjosti proti Jadranski obali. Topografija območja je precej razgibana, višine so v območju nekaj sto metrov. Sicer je za Apulijo značilno precej ravno karbonatno območje, ki je predstavljalo foreland bazen ob dvigu Apeninov v miocenu. Gričevje Murge delimo na dva območja: Visoke Murge, planota v notranjosti, kjer še lahko opazimo ostanke tropskega krasa in Nizke Murge, bližje obali, kjer je kraška morfologija na površju manj izrazita. Tu najdemo najpomembnejše jamske sisteme v Apuliji: jama Castellana, ki je od leta 1939 turistična jama in sistem Pozzo Cucù. Oba sistema sta med seboj oddaljena vsega nekaj sto metrov in skupaj presegata dolžino $5,5 \mathrm{~km}$. Poleg teh na območju najdemo še veliko drugih kraških jam različnega nastanka, od vadoznih brezen, medplastnih jam in jam razvitih ob tektonskih strukturah, do obmorskih jam. Tudi na površju najdemo številne oblike povezane z zakrasevanjem. Najpomembnejše je polje Canale di Pirro, ki seka SV območje gričevja Murge v smeri V-Z, njegov najvzhodnejši del pa doseže stopnjo v prelomni coni Murge. To je tudi glavna morfološka oblika, ki povezuje gričevje Murge $\mathrm{z}$ Jadransko ravnino. V članku predstavimo kraške morfološke oblike gričevja Murge. Z uporabo podatkov o površinskih in podzemnih oblikah poskušamo podati nove interpretacije procesov glavnih razvojnih faz omenjenega kraškega območja.

Ključne besede: geomorfologija, jame, polje. 


\section{INTRODUCTION}

Apulia is one of the main karst region in Italy, being characterized for most of its areal extent by soluble rocks. Geologically representing the foreland of the Apenninic Chain of southern Italy, it is made of a several thousands of meters-thick carbonate bedrock formed in Tertiary, that remained essentially undeformed during the phases of building up of the chain, which began in Miocene. Later on, it was covered by Quaternary clastic carbonates, and interested since the Lower Pleistocene by a general uplifting, until it reached the present configuration (Doglioni et al. 1994). The region is fragmented by high dip, mostly NW-SE striking, faults into uplifted and lowered blocks (Ricchetti et al. 1988; Bosellini \& Parente 1994).

The overall setting shows a monoclinal structure, with slight undulations, gently dipping toward SE. Lithologically, there is a great variability, ranging from micritic and sparitic limestones that constitute the great majority of the outcrops, to dolostones, and fossiliferous (mainly rudists) calcarenites.

The NW-SE elongated peninsula can be subdivided into three main karst sub-regions (Fig. 1): from $\mathrm{N}$ to $\mathrm{S}$, the Gargano promontory, reaching the maximum elevations in the Apulian karst landforms (higher than 1000 $m$ a.s.l.), the Murge plateau, and the Salento peninsula. This paper examines the Murge, the main karst area in central Apulia, extending some tens of kilometers inland from the Adriatic coastline. In turn, it can be subdivided into High Murge, and Low (or SE) Murge. By describing the main endokarst and subsurface morphologic features in the area (with the exclusion of the marine caves along the coastline), some considerations are presented here to provide a contribution to a better understanding of the surface and subsurface karst features in this sector of Apulia.

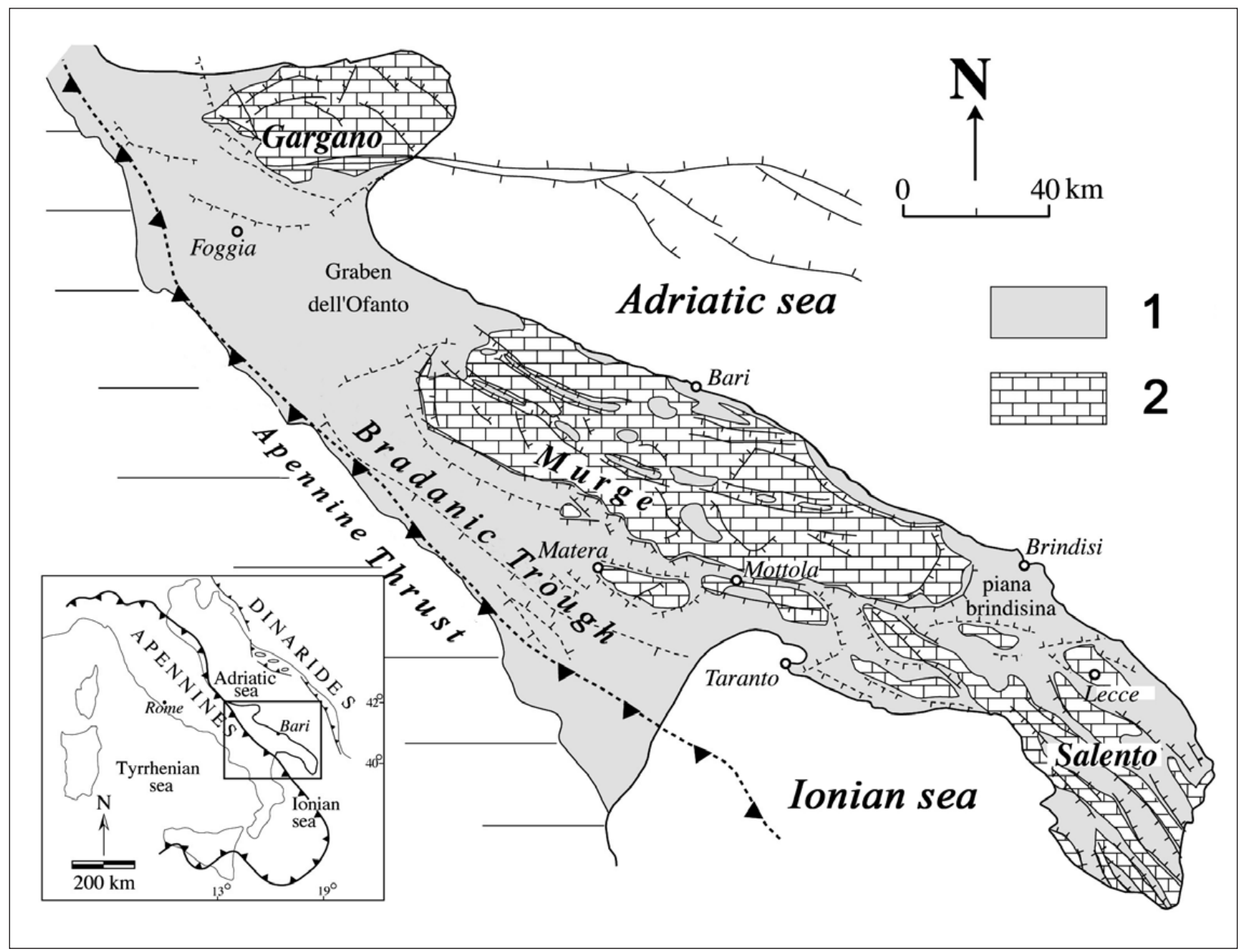

Fig.1: Geological sketch of Apulia (modified after Pieri et al. 1997): 1) Bradanic Trough sediments and terraced deposits (Pliocene-Pleistocene); 2) carbonate units of the Apulian Foreland (Mesozoic-Cenozoic). The three main karst areas of the region (Gargano, Murge, and Salento) are shown. 


\section{HIGH MURGE}

The High Murge is the upper portion of the plateau, elongated in NW-SE direction, and extending at elevations between 400 and $679 \mathrm{~m}$ a.s.l. (maximum elevation at Mt. Caccia). It is limited by step-like scarps, more evident on the south-western edge, whilst the north-eastern margin occurs through a series of small scarps and intervening benches. As interpreted by Sauro (1991), the High Murge plateau was an island in the Plio-Pleistocene sea, and the karstic processes began in the area not later than the upper Miocene. In the same article, the author describes the main surface features of the area as formed by a honeycomb complex of depressions, most of which present polygonal shape, which leads to describe them as polygonal karst.

As a whole, the landscape in High Murge is very articulated, with remnants of fluvio-karst landforms and several karst features (valleys, dolines, caves). Wide areas of High Murge are marked, in particular, by the presence of dolines, both as individual features and as coalescent landforms, giving origin to more complex depressions (Fig. 2). Morphometric analysis of the main 53 dolines identified on the 1:25,000 scale maps from the Italian Army Geographical Institute (IGM) indicate their likely genesis in a low relief cockpit karst (Sauro 1991). Over such landscape, developed in Upper Tertiary, a hydrographic pattern was superimposed, that partly opened some of the depressions, also dismantling sectors of the karst relief and producing talus deposits (Caldara \& Ciaranfi, 1988). Moving to a larger scale, analysis of the 1:5,000 scale topographic maps allows to recognize a much greater number of dolines, that appear to be mostly controlled in their development by the pattern of the main tectonic discontinuities in the rock mass, as also occurs in the overall hydrological pattern of karst valleys.

One of the largest dolines in the High Murge, the Pulo di Altamura, presents for instance two valleys entering it from different sides, and draining two distinct, several $\mathrm{km}^{2}$ wide catchments (Colamonico, 1916; Laragione et al. 2008). Within such a landform, several caves are present, both at the flanks of the doline and at its bottom, the most significant being Grava del Pulo, at

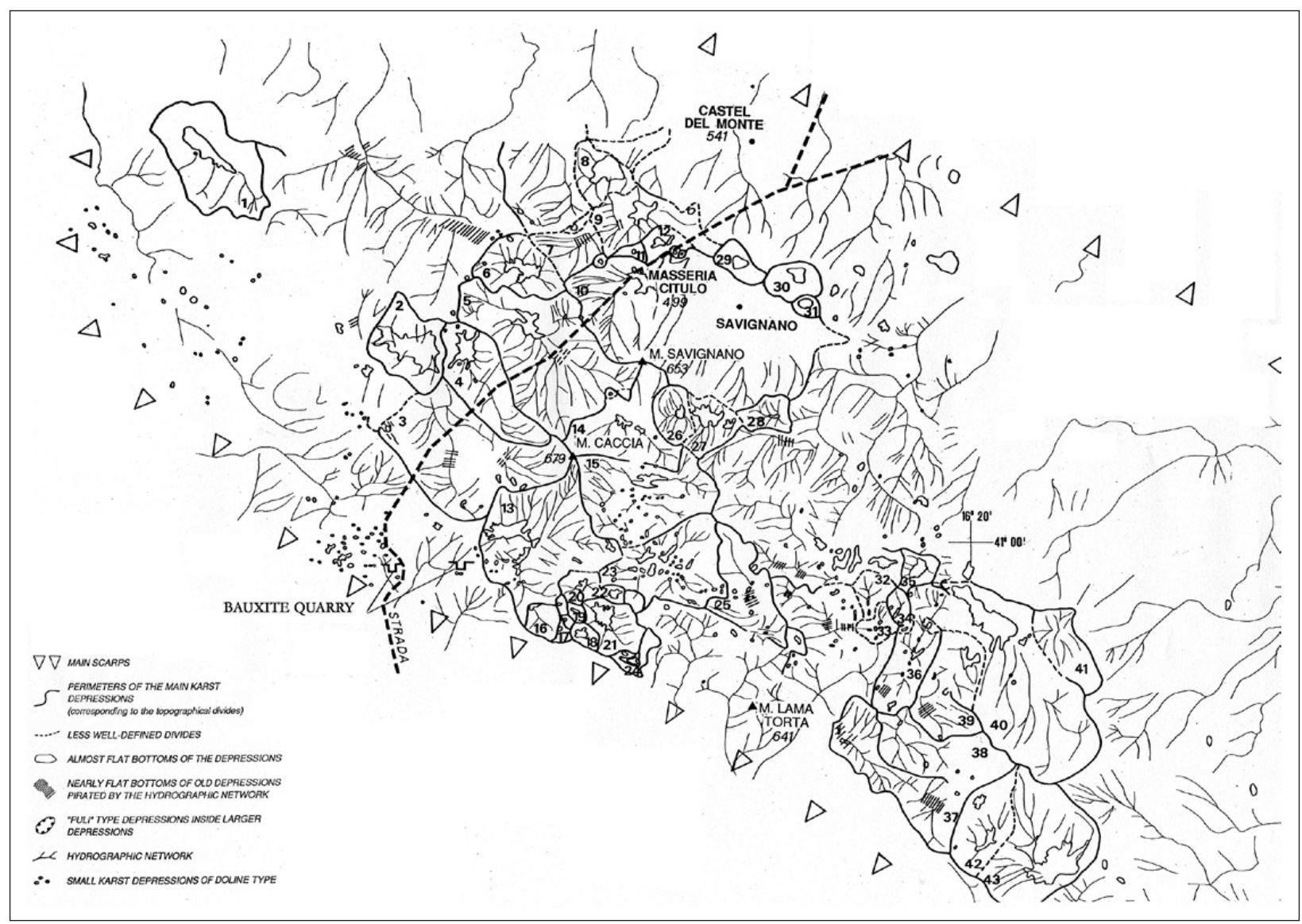

Fig.2: Geomorphology of a sector in the High Murge (simplified after Sauro 1991). 


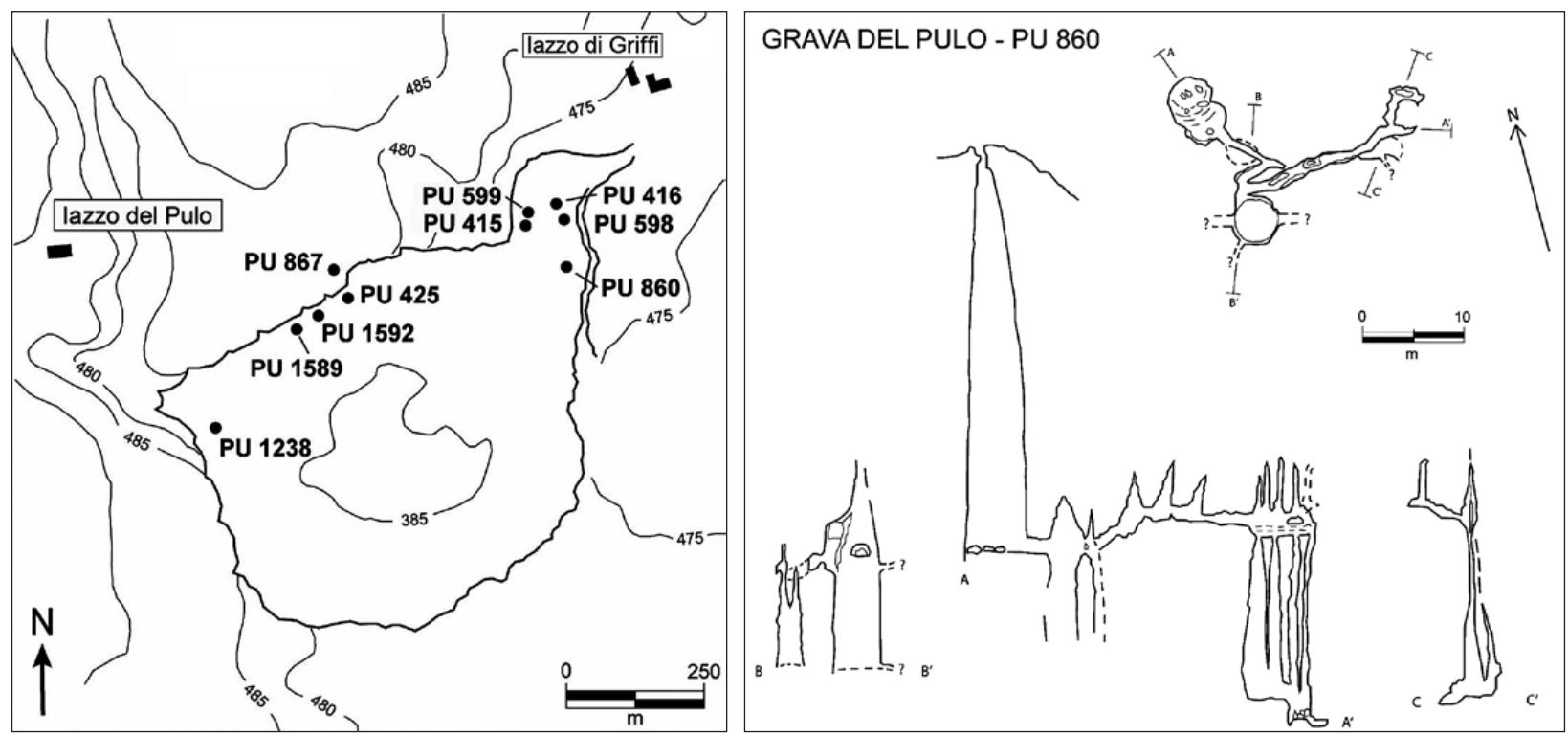

Fig.3: Pulo di Altamura, the largest doline in High Murge. Numbers in the figure to the left refer to the caves in the area (PU is for Puglia, followed by the Cadastrian number). The survey of Grava del Pulo (PU 860), the deepest cave in the area, is also shown (survey property of Federazione Speleologica Pugliese, redrawn).

the north-eastern corner, reaching about $60 \mathrm{~m}$ below the ground through a number of parallel vadose shafts (Fig. 3). Similarly, other large features are present in the Murge, showing karst voids of different sizes along the walls: commonly indicated with local dialectal terms as pulo or gurgo (Parise et al. 2003), these are probably related to multi-phase speleogenesis which exhumed and partly re-modeled old paleokarstic features. The alternative hypothesis of formation as a "cenote-type" depression, proposed by Castiglioni \& Sauro (2000) for the Pulo of Molfetta, seems less likely, based upon the available data.

In the Murge, the surface hydrographic pattern is characterized by the presence of shallow valleys with flat bottom, generally filled with thin residual deposits or terre rosse, and with a gradual passage to the adjoining slopes where carbonate rocks and fragments crop out. These valleys are locally called lame (from the latin lama, meaning pond, swamp; Parise et al. 2003), and therefore related to the presence of water at the ground surface. They represent the remnants of the original hydrographic network, and locally create a system leading up to the $3^{\text {rd }}$ or $4^{\text {th }}$ order, eventually finding their base level at the bottom of a depression or doline. The low relief of landforms such as lame make them particularly prone to be easily canceled by man's activities: agricultural practices that consist of removal and crushing of the stones from the fields have been intensively carried out in the last decades, leading to severe changes in the original karst landforms.

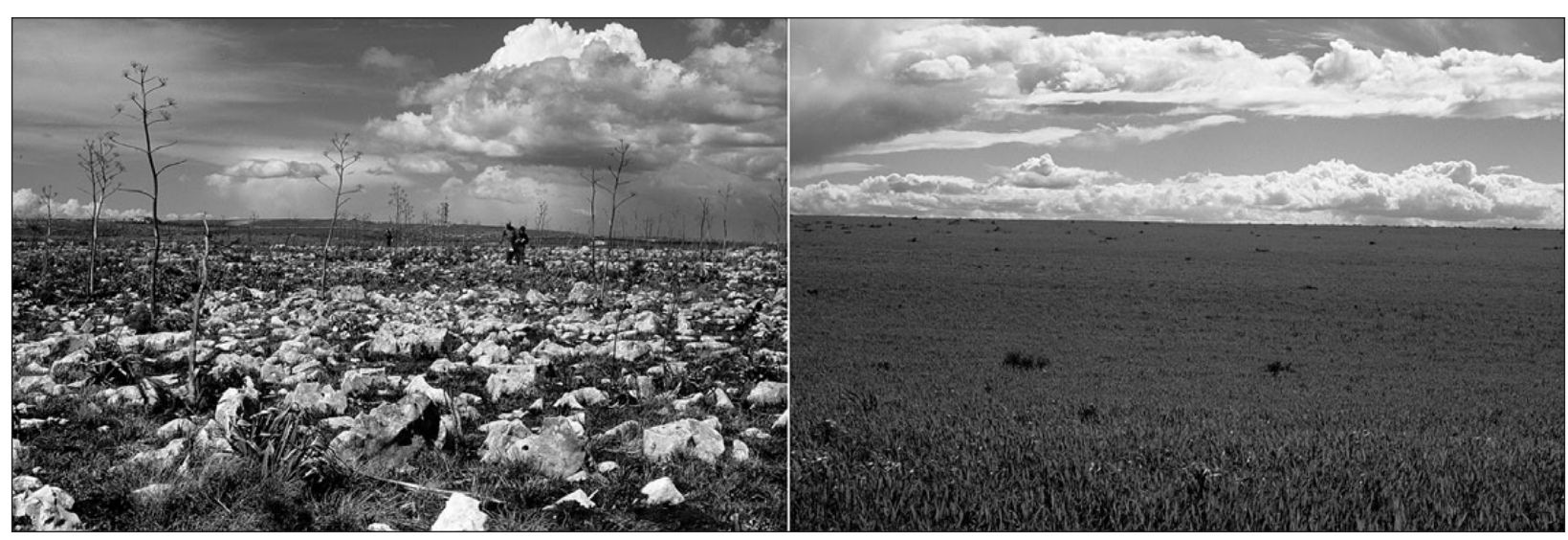

Fig.4: Typical karst landforms in the High Murge, showing the bare rock outcrops before (left) and after (right) the effects of intensive stone clearing. 


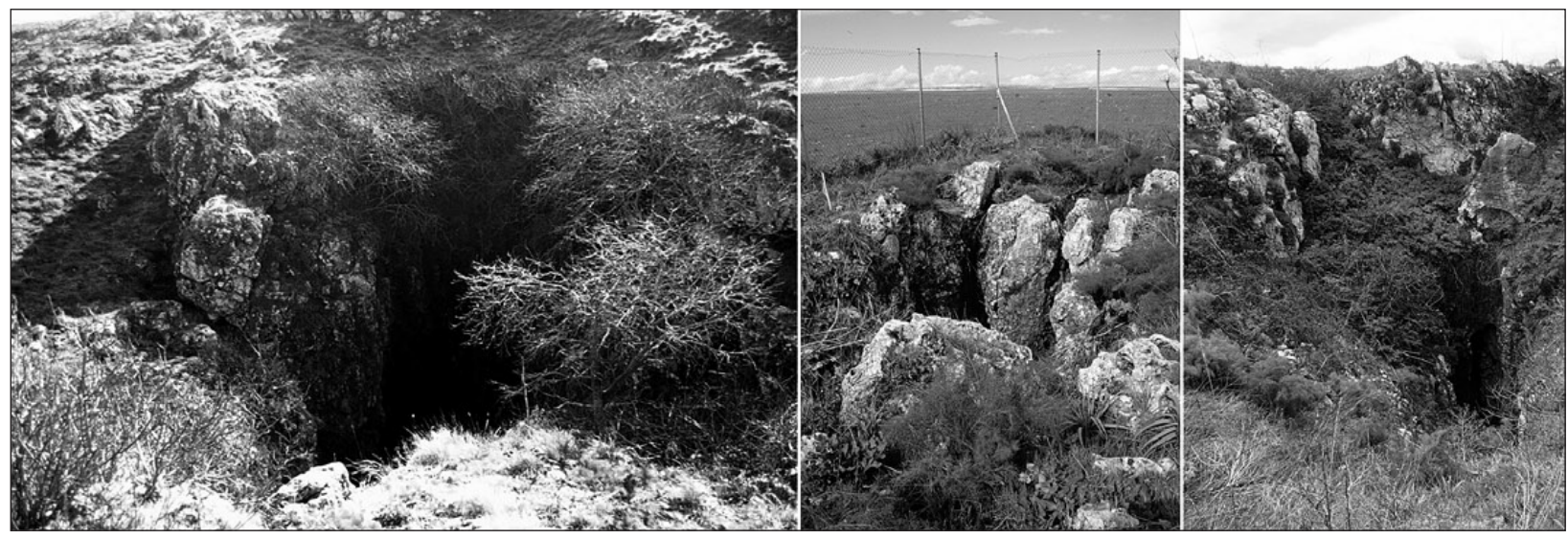

Fig.5: Cave entrances in the High Murge: from left to right, Faraualla cave (PU 31), Spinale di Porco (PU 814), and Povera Vita (PU 850).

Agriculture initially developed in the narrow strips of land where the presence of residual deposits allowed the establishment of thin soil layers, and/or in small depressions where water was able to be kept for a longer time within the epikarst. Outside of these sites, the karst landscape typically consisted of stony plateaus and subdued rounded hills (Fig. 4). To gain further space to agricultural practices, part of the surrounding stony areas was cleared of rocks: these were extracted by hand in the past, and used to build dry stone walls to delimitate the properties, and/or to act as a barrier to soil erosion or to terrace in the sectors with higher gradients. At the same time, extraction and re-use of carbonate rocks originated some of the most typical rural architecture in Apulia, as the cone-shaped trulli and masserie, very common countryside mansions in the area (Parise 2010). In the last decades of XX century, thanks to the use of modern technologies and machineries, and favoured by discutable policy of subsidies from the European Community, stone clearing was intensively performed. Wide sectors of Apulia were affected by land use changes, resulting in destruction of the epikarst (and of the karst ecosystems therein present as well) through removal of the stones, even of large size, crushing and production of a gravel-size field where to establish crops such as wheat or vineyards. Loss of the natural karst landscape (Calò \& Parise 2006; Parise 2010) was therefore registered over wide territories in the High Murge (Fig. 4). In addition, removal of the original soil had as direct consequence an increase in the erosional processes in occasion of main rainstorms, even at those sites characterized by low to very low gradients. Stones of larger size were often piled up near cave entrances, or dumped into caves and swallow holes, thus producing a serious danger to cavers, and sometimes making the access to important karst caves impossible.

One of the most important caves in Apulia, the Grave Ferratella, where the explorations carried out in the 1960's allowed to reach $320 \mathrm{~m}$ depth below the ground, and to ascertain the possibility of further explorations, has been lost due to agricultural works in the 80 's that caused its closure (Iurilli \& Ruina 1999). Nowadays, the precise location of the cave access is unknown. Also in several other cases (Fig. 5), the area surrounding the entrance of caves has completely changed in the last decades due to the stone clearing works, including some of the deepest in the area as Faraualla cave (about $250 \mathrm{~m}$ deep; Calella et al., 1987).

\section{LOW MURGE}

The morphology recognizable in the inner plateau of High Murge becomes even smoother in the Low or SE Murge, that is the portion of the karst area closest to the sea. However, some karst features are still present, to characterize the landscape both at the surface and underground. For instance, many locality names indicate the possibility of water accumulation at the surface, and this is a very important element in karst, where surface water supplies are generally more limited than in other natural settings, which results in greater human dependency on groundwater supplies than is the case in nonkarst regions with similar climates (Aley 2000). The few areas where there is possibility of presence of water at the surface becomes therefore of crucial importance as concerns foun- 
dation and developments of the human settlements. At this regard, perennial or temporary lakes in karst settings represent undoubtedly an uncommon and peculiar, if not remarkable, feature.

In the Low Murge, epikarst (Williams 2008) is limited to depth of a few meters; this means that, even though jointing in the rock mass is moderate to high, there is tapering closure of the solutionally enlarged joints rapidly with depth. In addition, these joints are also filled with red clays. Deposition of impervious terrains within the topographic depressions, then, is the final element which concurs to the development of karst lakes, or at least to seasonal or temporary presence of water at the surface.

Several lakes (Fig. 6), located at the bottom of dolines and slight depressions or valleys are present, with water throughout the year, or only after the main rain- fall events (Lopez et al. 2009). Infilling of the lakes consists mostly of residual deposits ranging from silty clays to silty sands, with local intercalations of volcaniclastic materials. Interlayering of deposits with different degree of permeability, resting over an intensely fractured and karstified carbonate bedrock, makes these materials the recharge area for the underlying deep aquifer in the Mesozoic limestones. In many cases, presence of these water resources played a remarkable role in man's history in Apulia, since many ancient settlements were established nearby these areas. Similar situations are also found in other sectors of Apulia, from the Gargano promontory to the Salento peninsula (Parise 2009).

The network of caves in the south-eastern Murge is among the most developed in Apulia, and include the longest and most famous karst system of the region, the Castellana Caves. First explored in January 1938, the

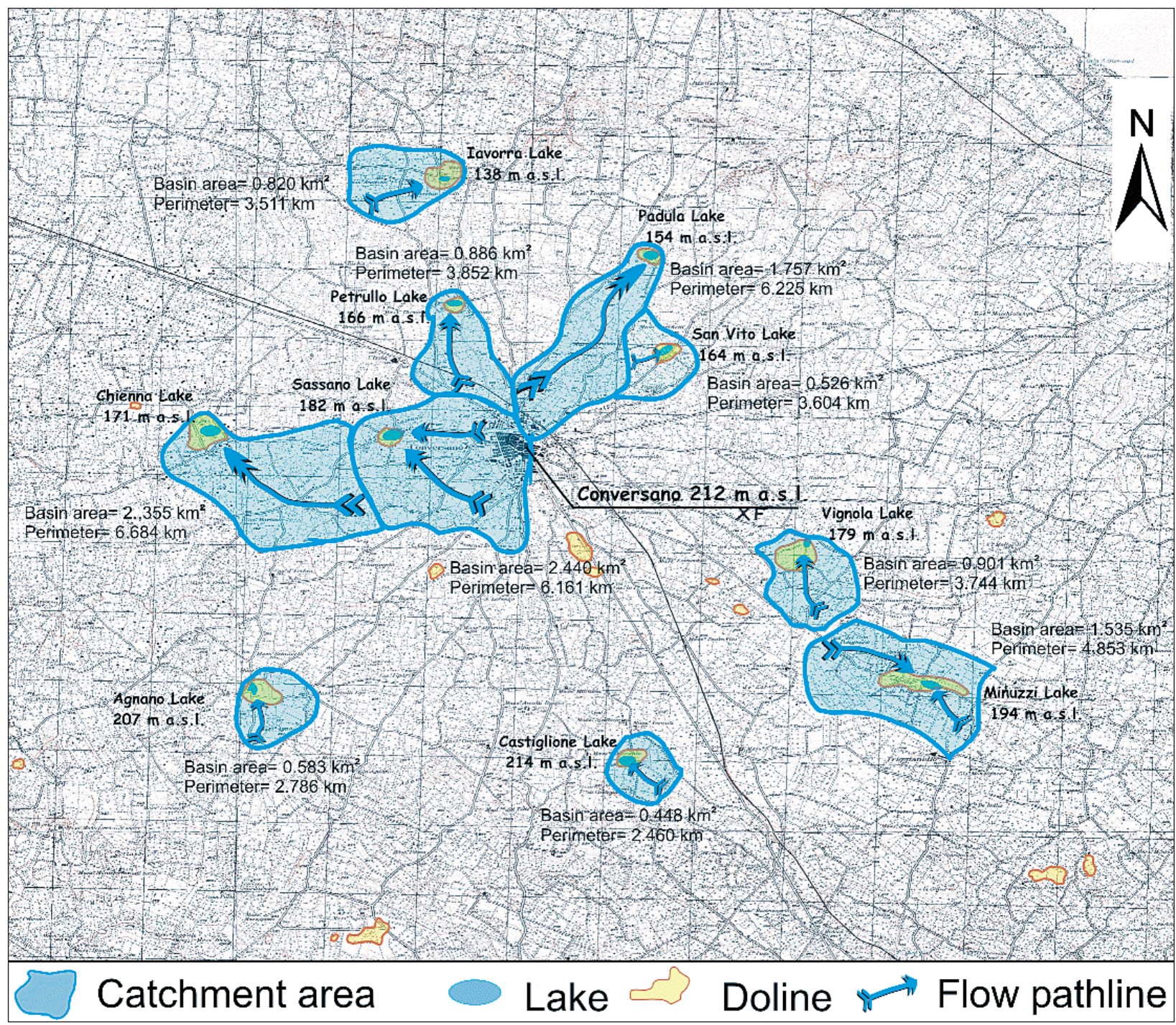

Fig.6: Catchment basins of the ten karst lakes in the territory of Conversano, SE Murge (after Lopez et al. 2009). 
caves were soon exploited as show cave (Anelli 1938, 1957). Nowadays, they host over 250,000 tourists per year. In the decades following the discovery the explorations continued to add new passages to the overall development, until reaching the presently known length of 3,348 meters, with a maximum depth of -122 meters (Fig. 7). As for most of the caves in this territory, the Castellana Caves have a prevailingly sub-horizontal pattern, with large caverns, whose height ranges from a few meters to some tens of meters, and intervening corridors; development of the latter is frequently controlled by the main discontinuity systems in the rock mass. Examination of the diagrams showing the main directions of development of the caves and of those expressing the tectonic discontinuities indicates a primary role of tec- tonics in the origin of the main cave systems at Castellana and surrounding areas, in agreement to what recently observed farther south, still in the Murge area (Iurilli et al. 2009). The karst system develops for most of its total length at about $70 \mathrm{~m}$ below the ground, which is the level where the tourist path develops. Below this level, the cave reaches the maximum depth $(-122 \mathrm{~m}$ below the ground) through a number of shafts, the most significant being present at both the sides of a wide cavern, which bottom is clogged by a chaotic mass of breakdown deposits (Fig. 8; Parise et al. 2002). As observed also in several other caves in the Castellana-Grotte area, the deepest portions in the karst system are often accompanied by high concentrations of $\mathrm{CO}_{2}$, which makes difficult to continue the explorations.
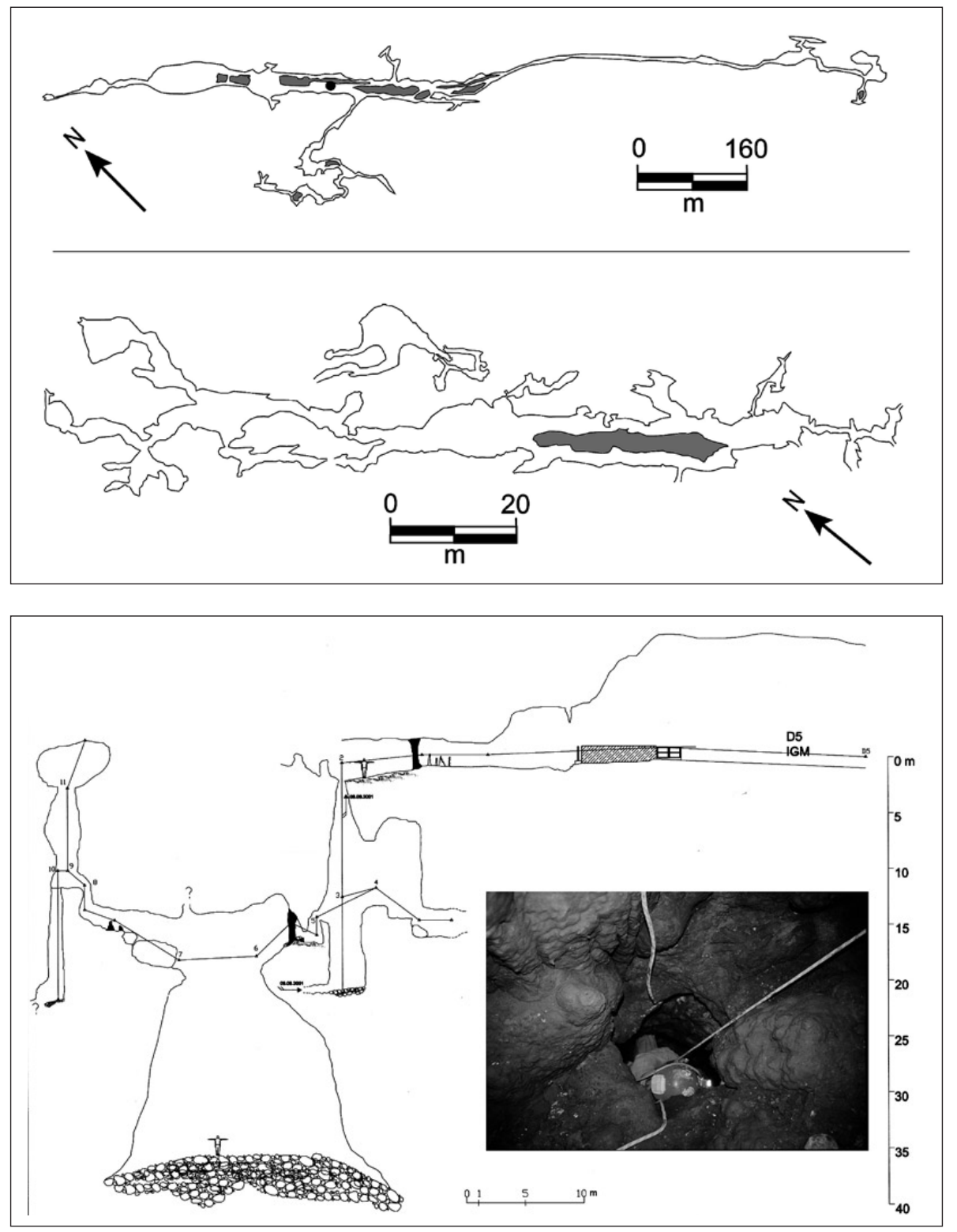

Fig.7: Planimetry of Castellana Caves (above) and Pozzo Cucù (below); surveys property of Federazione Speleologica Pugliese. Black dot in the Castellana Caves plan indicates location of the shafts shown in figure 8.

Fig.8: Section at the deepest parts of the Castellana Caves (for location see Fig. 7), showing the two series of shafts leading to the intervening wide cavern (maximum depth $-122 \mathrm{~m}$ below ground). Survey by GPG, Castellana-Grotte. The picture shows the narrow access to one of the shafts. 
The Castellana Caves open in a stratified limestone of Upper Cretaceous age (Parise \& Reina 2002), which can be classified as a hard rock with crystalline texture and isotropic structure at the laboratory specimen scale, whilst, at the rock mass scale, it is an anisotropic rock due to moderately spaced bedding planes (Lollino et al. 2004). The rock mass is intensely fractured, and locally shows arching and deformations in the limestone strata (Diederichs \& Kaiser 1999). The karst system at Castellana-Grotte is multi-phase, having initially formed when the limestone rock mass was saturated beneath a water table, and later evolved when the water table lowered. As a result, the original network of tubular phreatic caves was modified by subsequent phases of vadose caves, mostly characterized by canyon-like features. In turn, these passages later changed through breakdown processes (Parise \& Trisciuzzi 2007), and were partly or completely filled by allogenic sediments and secondary calcite deposits. In some rooms, corresponding to that part in the lithological succession where thickness of the strata is lower, the progressive failures of the unstable roof easily created an increasing pile of rock debris, and the upward migration of the void. At these locations, the original dissolutional cave may therefore be at depth much greater, below the several meters-thick debris.

Recently, some features in the Castellana karst systems (namely, rising wall channels originating from the top of cupolas) have been interpreted as related to hypogenic conditions (Galdenzi 2009), and considered as having a similar origin to subterranean morphologies such as bubble trails (Klimchouk 2007). Attribution of these karst features to hypogene caves is, however, a matter of debate in the area, and still needs further analysis and work.

The Castellana caves are not the unique karst evidence in the territory of this small town in south-eastern Murge: the whole area, as well as the territories of the nearby towns, is typically karst, marked by the presence of peculiar surface karst landforms and numerous caves. At the surface, dolines represent the dominating landform: very frequently, due to the long history of human presence, they have been modified by man, or accommodated to host some of the most typical agricultural products of the area, from olive trees to almond to cherries. The locally steep slopes bounding the dolines have often been sustained through realization of stone dry walls, by using the typical local bedrock (Gams et al. 1993).

Karst valleys are the other category of surface landforms: Canale di Pirro is definitely the most important, being a 12-km long polje which extends from inland Murge to the Adriatic Sea coastline (Neboit 1975; Parise 2006). Lame are, on the other hand, less prominent but more diffuse. In occasion of the most intense, and/or long lasting, rainfall events, lame are still marked by water flowing, whilst often the anthropogenic changes of their original courses is responsible for flooding events (Parise 2003).

In regard to karst caves, besides the aforementioned Castellana show caves, the most interesting area is the sector where the Pozzo Cucù karst system opens (Fig. 9): located just a couple of kilometers outside the town limits, this area hosts at least four caves, among which Pozzo Cucù (PU 1200) is the longest, with over $1,5 \mathrm{~km}$ of passages. The overall development of the cave is highly controlled by tectonics (see below), as well as the karst landforms at the surface: these latter are essentially represented by elongated and narrow lame that drain a few $\mathrm{km}^{2}$ wide endhoreic basins, or terminate in correspondence of dolines, where caves locally open (see, for instance, PU 11 in Fig. 9).

The Pozzo Cucù caves develop mostly horizontally, with the exception of the sequence of two shafts at the access, that are deep, respectively, 6 and 7 meters. Through these shafts, and the intervening narrow passage, the main level of cave development is reached, at elevation around $250-260 \mathrm{~m}$ a.s.l. It has to be noted that this elevation is the same of the main level at the Castellana show cave, which highlights that the two karst systems were formed during the same speleogenetic phase. Pozzo Cucù cave consists of two branches (Fig. 7), distinguished according to the directions of development in SE and NW branches. The SE branch is characterized by wide caverns where the role played by gravity has been extremely important in enlarging the original rooms and conduits. Frequent breakdown deposits, even involving great volumes of rocks, mark the cave floor (Fig. 10b). In this branch, several features are worth to be mentioned, including a wide sinkhole at the cave floor, which caused lowering of the passage for some meters, thus reaching a deeper level below, and a cavern about at the end of the SE branch, that was probably the original natural access to the system; currently it is clogged at the surface and shows a $12 \mathrm{~m}$ high and wide debris talus. The NW branch is quite different, being characterized by low intrastratal galleries, and by intervening rooms where cavers may reach again the vertical position. At the terminal part of the branch, height of the passages further lowers, forcing to move within very narrow passages, up to the terminal room, closed by rockfall deposits. At Pozzo Cucù, several features have been identified as possibly relating some parts of the karst system to hypogene caves: i) ceiling pockets, locally developed along fractures (Fig. 10a), and ii) cupola-form solution pockets at the ceiling, highlighted by horizontal bedding in the rock mass. Since there is no hydrological connection with the overlying beds, the cupolas were probably formed by convection cellular 
water flow within the cave. Research on this topic is still in progress, in the attempt to identify morphologies related to hypogene processes.

Weathering of carbonates occurs through the three main processes that produce degradation of the physical and mechanical properties in the rock mass (Fookes \& Hawkins 1988; Lauritzen \& Lundberg 2000; Zupan Hajna 2003): chemical processes, mechanical rock weathering, and biological effects. All of these determined the pro- duction of rock blocks and fragments that, together with the mostly clay materials transported by floods, constitute the bottom of large sectors in the cave systems (Fig. 10c). The presence of the alluvial sediments and breakdown deposits causes, in turn, development of paragenesis, that is the enlargement of the cave channels by corrosion above the aforementioned deposits (Renault 1968; Ford \& Ewers 1978; Pasini 2009). The thicker weathered zones are found at those locations where the walls are in contact with clastic sediments, and wet because of condense water. At such sites, in fact, the weathered material is protected against mechanical erosion. In most of the cases, the weathered zones are covered by flowstone layers of predominantly brownish red colour.

Within the Pozzo Cucù system, clay deposits have been found at several locations (Fig. 10d), left behind by flood events into the cave, or deriving from slow deposition once the main level of the karst system was abandoned by the water. Analysis of the latter sediments, (reddish at the bottom, and black at the top, then sealed by an alabaster crust), allowed to identify the presence of clay minerals as caolinite, illite, and muscovite, and of $\mathrm{Fe}, \mathrm{Mn}$ and $\mathrm{Ti}$ oxides as well; based upon mineralogy of the deposits,

Fig.9: Geomorphological map of the area surrounding the Pozzo Cucù karst system. Key: 1) karst valleys (lame); 2) temporary water lines; 3) ridge; 4) morphologic saddle; 5) doline; 6) quarry; 7) cave entrance (PU is for Puglia, followed by the Cadastrian number); 8) urban area. 


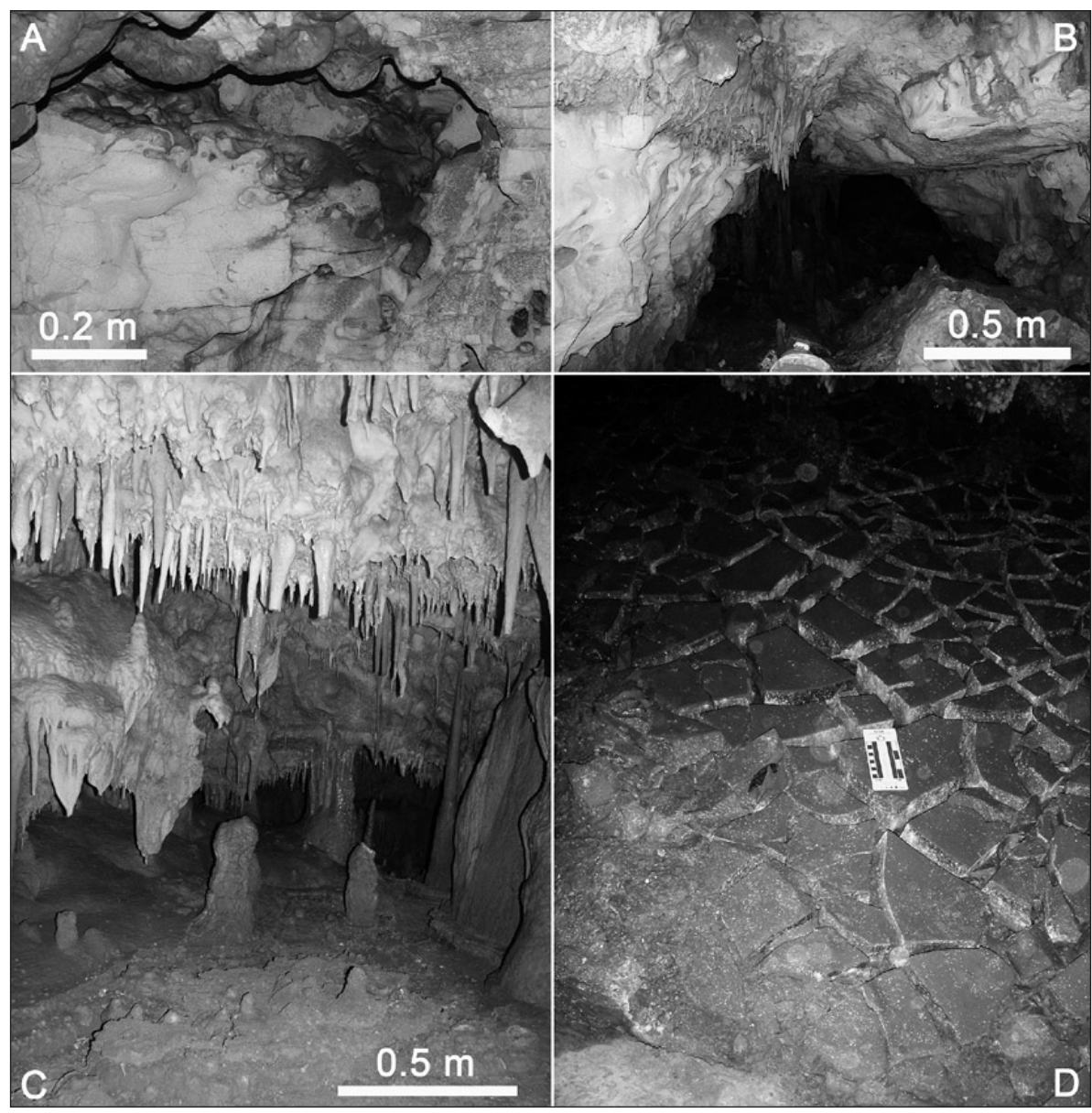

Fig.10: Pozzo Cucù karst system: a) solution pockets at the ceiling; b) a passage in the SE branch, showing the large breakdown deposits at the floor, and the flowstone coverage on the right wall; c) stalactites and flowstones characterize long sectors in the cave system, whilst the floor is marked by presence of clay sediments; d) polygon cracks in the half $m$ deep mud deposits present in the vicinity of the cave entrance.

(Fig. 11a) is that related to formation of the cave: during this period, circulation of aggressive water led to enlargement of the cave system. The second stage corresponded to infiltration of waters that at the surface were capable to mobilize $\mathrm{Fe}$ and $\mathrm{Mn}$ from the soil, but then lost their aggressiveness in the cave environment, allowing the deposition of Fe and Mn hy-

integrated with analysis of the morphology in the caves, the different phases of evolution in the cave system were reconstructed (Fig. 11; Forti et al. 1985). The first stage droxides (Fig. 11a, b). Later on, the time of formation of the crust above the clay deposits is still related to alkaline waters, followed by infilling of the cave by clays and

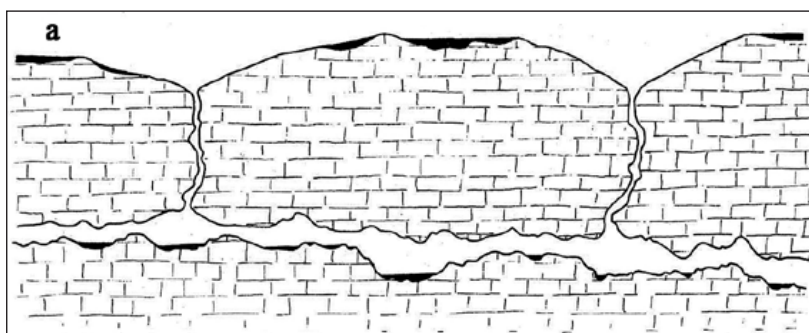

c

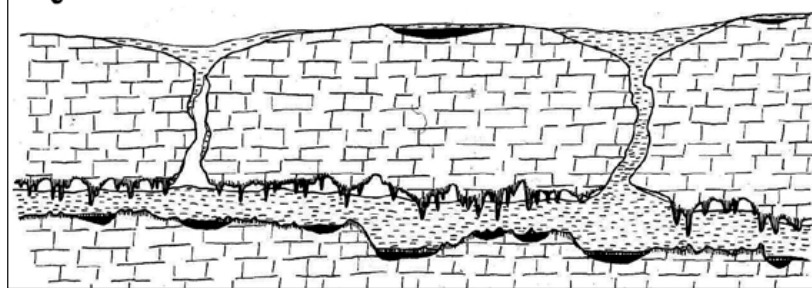

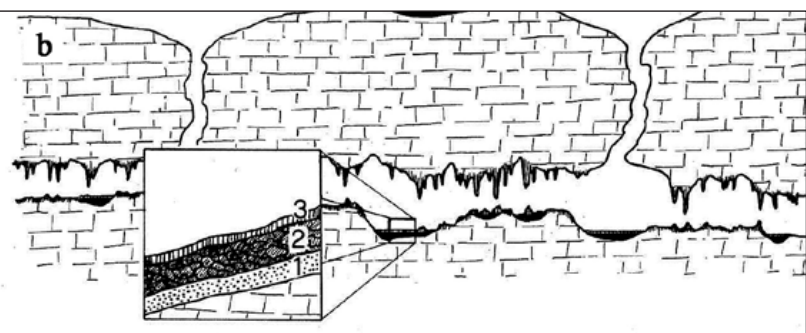

d

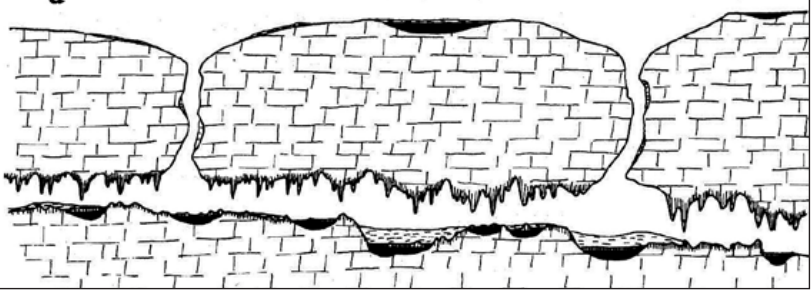

Fig.11: Speleogenesis evolution in the Pozzo Cucu karst system, as reconstructed from the examination of the black sediments (modified after Forti et al. 1985): a) $1^{\text {st }}$ stage, with formation of the cave, and $2^{\text {nd }}$ stage, with beginning of the sedimentation of Fe and Mn hydroxides; b) formation of the crust concretions covering the Fe and Mn deposits (in the inset, 1 is the brown-red level, 2 the black level, 3 the crust); c) $3^{\text {rd }}$ stage, with almost total filling of the cave; d) present situation, when the cave was partially emptied of the cave deposits. 
silts (Fig. 11c). The infilling was locally complete, as can be observed by clay pockets at the highest parts of walls and ceiling, and was then followed by partial emptying of the cave system by flowing rivers (Fig. 11d), that favoured also the development of a second, deeper level of cave formation. This latter, placed a few meters below the main one, consists of narrow, greatly decorated, passages separated by breakdown deposits that make the lower level discontinuously developed.

\section{SOUTH OF LOW MURGE: THE TRANSITION AREA TO SALENTO PENINSULA}

The Murge fault line scarp is the most striking feature between SE Murge and the Salento peninsula: it can be followed for length of several kilometers, along its NW-SE strike, and has the best morphologic expressions in the surroundings of Fasano and Ostuni (Fig. 12), where the scarp clearly separates the plateau from the sequence of terraces toward the sea. At the inner knick point of some of the terraces (Fig. 13), caves or cave systems open, generally formed at the contact between two different types of limestones: the micritic limestone that makes up the backbone of most of Apulia region, and an Upper Cretaceous fossiliferous and less resistant formation, consisting of calcarenites and calcirudites. The stratigraphic contact is very sharp and can be easily followed, also marked by a number of caves and rock shelters, beside the selective erosion landforms.

Along the coastal strip from the SE Murge farther south to Salento Peninsula, medium to coarse size PlioPleistocene bioclastic calcareous arenites, marly calcareous arenites and calcareous marls represent the main

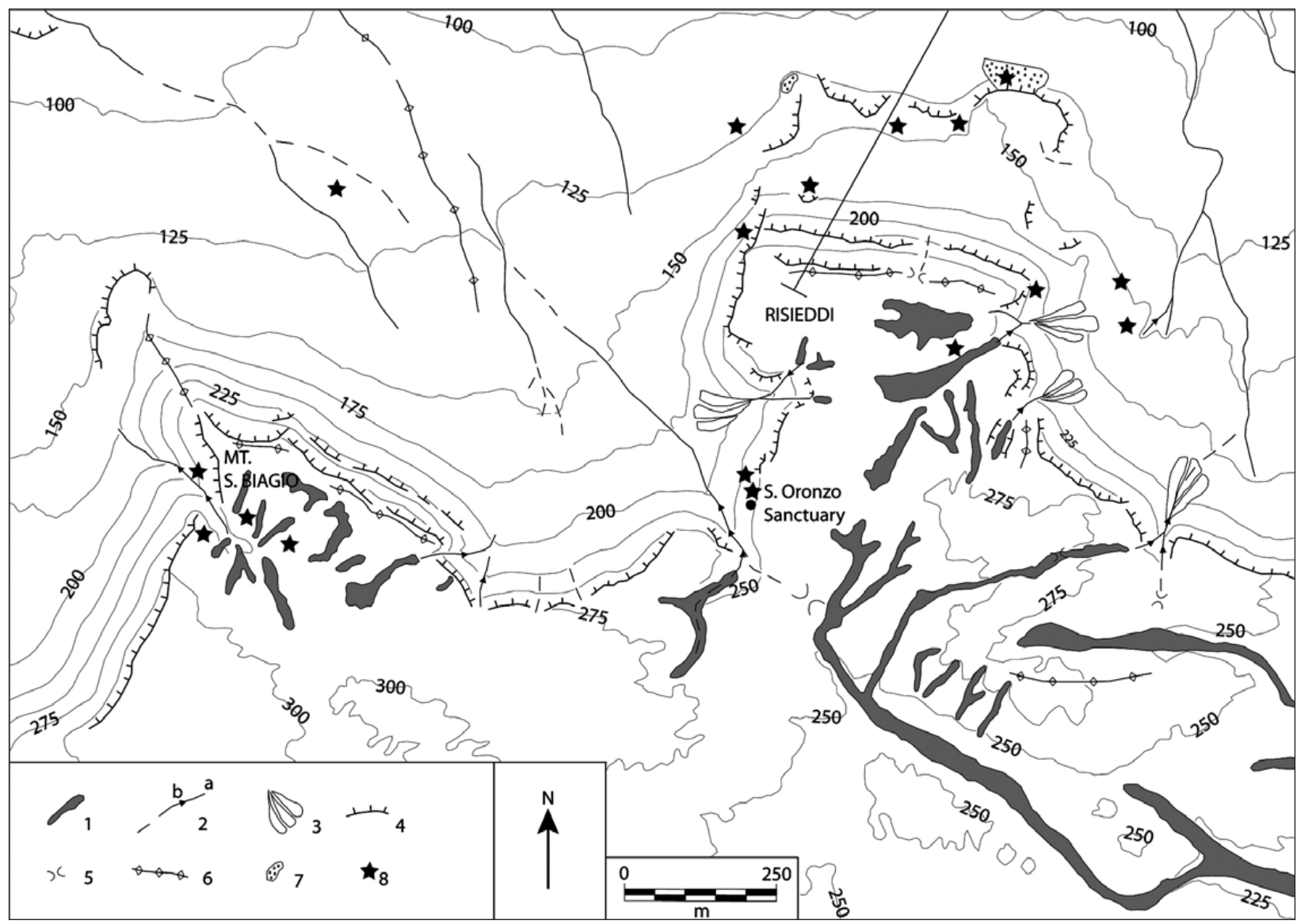

Fig.12: Geomorphological sketch N of Ostuni. Key: 1) karst valleys (lame); 2) temporary water lines, dashed where presumed (a), locally in incision (b); 3) fan; 4) scarp; 5) morphologic saddle; 6) ridge; 7) quarry; 8) cave entrance. Trace of the section of figure 13 is shown in the upper portion of the figure. 


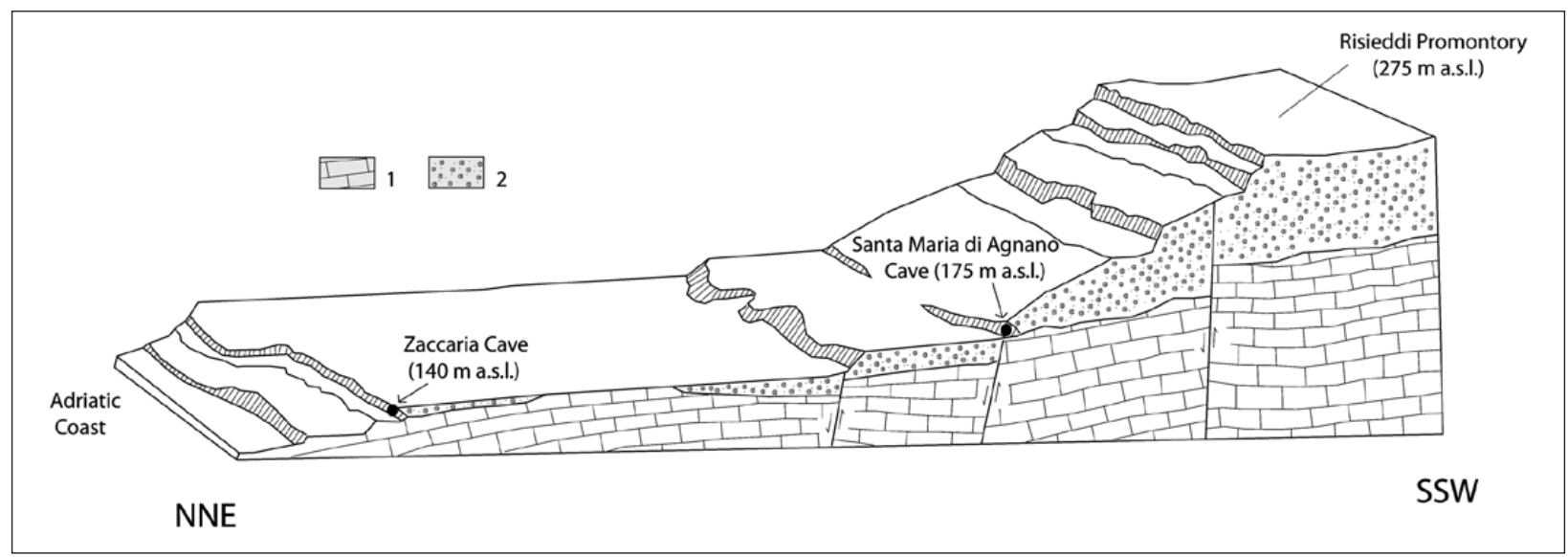

Fig.13: Sketch section from the Adriatic sea to the Ostuni area, showing the series of terraces and the location of the main caves. Key: 1) Altamura Limestone: micritic limestones; 2) Ostuni Limestone: biogenic limestones, calcarenites and calcirudites (Upper Campanian - Maastrichtian). Trace of section partially shown in figure 12.

geologic units, resting transgressively over the underlying limestone bedrock of Cretaceous age. The coastal landscape of the Adriatic side of Apulia is characterized by a number of marine terraces resulting from the combined action of regional uplift and glacio-eustatic sea level changes (Di Geronimo 1970; Bruno et al. 1995; Mastronuzzi \& Sansò 2002; Parise 2006). Some of them present thin calcareous sandstones, whilst the lower terraces, cut on the Plio-Pleistocene calcareous arenites, are generally represented by abrasion platforms, without the presence of sedimentary bodies. Regional geomorphological evidence suggests that the formation of the terraces most likely occurred during the Middle-Upper Pleistocene high sea level stands (Dini et al. 2000). Near the coastline, several cavities are prone to development by dissolution at the interface between salt and fresh water at either current or past sea levels (Rudnicki 1980). Karst morphologies are widely present, and include dissolution pipes that have been recently described in detail by specific studies, even in relation with similar forms in other sites of the Mediterranean basin (De Waele et al., 2011).

In correspondence of the high-gradient slopes, a type of karst valley very different from the lame earlier described, is observed. These valleys, named gravine (after the pre-latin term grava, meaning pit, hole; Parise et al., 2003) are deep and narrow canyons incised in carbonate rocks, with the bottom usually flat, which appears to be dry except when a river flows, after heavy rainstorms. They have their best morphological expres- sion at the Apulia-Basilicata border, where some tens of several-km-long gravine characterize the territory. Due to presence of alluvial deposits within several valleys, to other fluvial landforms in the gravine network, and to a number of geological evidence (see Colamonico 1953; Palagiano, 1965; Parise et al., 2003) they appear to have been formed as fluvio-karst landforms. Thus, sapping (Baker, 1990; Dunne, 1990; Nash 1996) considered by some authors as the "leading role process in the genesis of these valleys" (Mastronuzzi \& Sansò 2002) is not, in the author's opinion, sufficient to fully explain development of the gravine system. If active at all, sapping could have only played a minor and local role in the terminal portion of the valley, toward the sea (as shown in the model of coastal karst caves speleogenesis by Delle Rose \& Parise 2003), but the leading one had to be played by overland flow and fluvial incision. In addition, it has to be pointed out that many differences exist between lama and gravina, in terms of morphology, geology, hydrology, and structure. These differences are well highlighted by the etymology of the terms, with lama which is related to surficial presence and/or flowing of water, and gravina that, on the other hand, is clearly associated to the idea of depth. Considering these very distinct landforms simply as karst valleys (Mastronuzzi \& Sansò 2002), without making a clear distinction between the two, in terms of both genesis and hydrologic functioning, is therefore a possible source of misunderstanding and confusion, and should be definitely avoided. 


\section{DISCUSSION}

The Murge, with particular regard to Low Murge, are an important karst area of Apulia, that still deserve detailed research in order to better define the phases of speleogenetic evolution in the region. The present paper, putting together material from the available literature and original data from the author's direct experience, represents an effort in this direction.

Given the low relief of Apulia, and the long history of occupation of this territory by man, many ancient remnants of the original karst landscape have been, or are being, lost. This is particularly true for the last decades, when an often uncontrolled urban expansions characterized wide areas of Apulia, and many traces of the historical heritage have been irrimediably destroyed. In other cases, landforms as lakes, or the slight depressions once they occupied, and karst caves and swallow holes, have become sites of frequent discharge of solid and liquid wastes, with severe consequences to the natural environment, the karst ecosystem, and the quality of groundwater. Pollution and degradation events are continuously registered in Apulia, as well as in many other italian regions. Analysis of the effects produced by man in the karst landscape, evaluated by means of the recently proposed Karst Disturbance Index (Van Beynen \& Townsend 2005), have shown a level of "significant" (close to the threshold with "severe") disturbance induced by anthropogenic activities in the Murge area (Calò \& Parise 2006; North et al. 2009). Mismanagement of this karst area is therefore at the origin of the overall degradation, of the frequent episodes of pollution, and of the flooding events. Even though these latter are generally classified as natural hazards (Parise \& Gunn 2007;
Andriani \& Walsh 2008; Polemio 2010), the negative effects they produce to the built-up environment are without any doubt amplified by improper man's actions.

The origin in the development of the largest karst features observed in the Murge (pulo and gurgo) is definitely one of the most interesting aspects to study. The different hypotheses so far presented (from collapse sinkholes, to re-elaboration of paleokarst landforms, to influence of sea level oscillations, etc.) should be better checked by thorough analysis of the caves within these large karst depressions. A further point worth to be analyzed in the next future is the possibility of hypogenic cave formation for some of the karst systems in the area. Hypogenic caves have generally a multistage evolution, related to the progressive deepening of the surface streams and of the related base levels. Even though the general setting in Apulia is not favorable for the development of such caves (ideally, hypogene caves are mostly located in small limestone outcrops covered by lowpermeability strata), the rise of sulfidic water has been proved at some localities. It has to be noted, however, that these are not located in the Murge but farther south, along the Adriatic coast of Salento.

In conclusion, several issues still needs to be studied in the Murge area of the Apulian karst: these include, but are not limited to, the paleokarst deposits which best expressions are preserved in High Murge, the terraced landforms from the Murge plateau to the Adriatic coastline, the formation of karst valleys, the relations between cave development and surface karst landforms, and the coastal karst.

\section{REFERENCES}

Aley, T., 2000: Water and land-use problems in areas of conduit aquifers.- In Klimchouk A.B., Ford D.C, Palmer A.N. \& W. Dreybrodt, (eds.), Speleogenesis. Evolution of karst aquifers. National Speleological Society, Huntsville, Alabama, pp. 481-484.

Andriani, G.F. \& N. Walsh, 2009: An example of the effects of anthropogenic changes on natural environment in the Apulian karst (southern Italy).- Environmental Geology, 58, 313-325.

Anelli, F., 1938: First researches of the Italian Institute of Speleology in the Murge of Bari. [in italian]- Le Grotte d'Italia, 2, 3, 11-34.
Anelli, F., 1957: Guide to the excursion II. Bari-Alberobello-Selva di Fasano-Castellana Grotte- Bari. [in italian]- Proc. XVII Italian Congr. Geography, 2329 April 1957, 69-120.

Baker, V.R., 1990: Spring sapping and valley network development. - In: Higgins, C.G. \& D.R. Coates, (Eds.): Groundwater geomorphology. Geological Society of America spec. paper 252, pp. 235-265.

Bosellini, A. \& M. Parente, 1994: The Apulia Platform margin in the Salento peninsula (southern Italy).Giornale di Geologia, 56, 2, 167-177. 
Bruno, G., Del Gaudio, V., Mascia, U. \& G. Ruina, 1995: Numerical analysis of morphology in relation to coastline variations and karstic phenomena in the southeastern Murge (Apulia, Italy).Geomorphology, 12, 313-322.

Caldara, M. \& N. Ciaranfi, 1988: Quaternary poliphasic breccias of northern Murge. [in italian]- Memorie Società Geologica Italiana, 41, 685-695.

Calella, P., Marraffa, M., Palmisano, P. \& E. Pascali, 1987: Grave of Faraualla [in italian].- Itinerari Speleologici, 2, 5-12.

Calò, F. \& M. Parise, 2006: Evaluating the human disturbance to karst environments in southern Italy.- Acta Carsologica, 35 (2), 47-56.

Castiglioni, B. \& U. Sauro, 2000: Large collapse dolines in Puglia (southern Italy): the cases of "Dolina Pozzatina" in the Gargano Plateau and of "Puli" in the Murge.- Acta Carsologica, 29 (2), 83-93.

Colamonico, C., 1916: The Pulo of Altamura. [in italian]Mondo Sotterraneo, 13, 65-76.

Colamonico, C., 1953: Lame and gravine in Apulia. [in italian]- Le Vie d'Italia, 11, 704.

Delle Rose, M. \& M. Parise, 2003: The control of geological-structural and hydrogeological factors in the speleogenesis of coastal caves in Salento. [in italian]- In: Proc. XIX Nat. Congr. Spel., Bologna, $27-$ 31 August 2003, pp. 27-36.

De Waele, J., Lauritzen, S.E. \& M. Parise, 2011: On the formation of dissolution pipes in quaternary coastal calcarenites in Mediterranean settings.-

Diederichs, M.S. \& P.K. Kaiser, 1999: Tensile strength and abutment relaxation as failure control mechanisms in underground excavations.- Int. J. Rock Mechanics and Mining Science, 36, 69-96.

Di Geronimo, I, 1970: Geomorphology of the adriatic slope of SE Murge (Ostuni area, Brindisi). [in italian]- Geologica Romana, 9, 47-58.

Dini, M., Mastronuzzi, G. \& P. Sansò, 2000: The effects of relative sea-level changes on the coastal morphology of southern Apulia (Italy) during the Holocene.In: Slaymaker, O. (ed.), Geomorphology, human activity, and global environmental changes, John Wiley \& Sons, New York, pp. 43-66.

Doglioni, C., Mongelli, F. \& P. Pieri, 1994: The Puglia uplift (SE Italy): an anomaly in the foreland of the Apenninic subduction due to buckling of a thick continental lithosphere.- Tectonics, 13, 1309-1321.

Dunne, T., 1990: Hydrology, mechanics, and geomorphic implications of erosion by subsurface flow. - In: Higgins, C.G. \& D.R. Coates, (Eds.): Groundwater geomorphology. Geological Society of America spec. paper 252, pp. 1-28.
Fookes, P.G. \& A.B. Hawkins, 1988: Limestone weathering: its engineering significance and a proposed classification scheme.- Quarterly Journal of Engineering Geology, 21, 7-31.

Ford, D.C. \& R.O. Ewers, 1978: The development of limestone cave systems in the dimension of length and depth.- Canadian Journal of Earth Sciences, 15 (11), 1783-1798.

Forti, P., Pini, A. \& E. Rabbi, 1985: Study of the black sediments in the Pozzo Cucù cave (1200 Pu) (Castellana-Grotte, Bari). [in italian]- Proc. $1^{\text {st }}$ Congr. Apulian Speleol., Castellana-Grotte, 6-7 June 1981, 79-86.

Galdenzi, S., 2009: Hypogene caves in the Apennines (Italy).- In: Klimchouk, A. \& D. Ford, (eds.) Hypogene speleogenesis and karst hydrogeology of artesian basins, Ukranian Institute of Speleology and Karstology, sp. paper 1, pp. 101-115.

Gams, I., Nicod, J., Julian, M., Anthony, E. \& U. Sauro, 1993: Environmental change and human impact on the Mediterranean karsts of France, Italy and the Dinaric region.- Catena, suppl. 25, 59-98.

Iurilli, V. \& G. Ruina, 1999: Geologic and geophysical surveys on Grave "Ferratella" in the municipality of Ruvo di Puglia (Bari). [in italian]- Itinerari Speleologici, 8, 23-30.

Iurilli, V., Cacciapaglia, G., Selleri, G., Palmentola, G. \& G. Mastronuzzi, 2009: Karst morphogenesis and tectonics in south-eastern Murge (Apulia, Italy).Geogr. Fis. Dinam. Quat., 32, 145-155.

Klimchouk, A., 2007: Hypogene speleogenesis: hydrogeological and morphogenetic perspective. National Cave and Karst Research Institute, sp. paper 1, pp. 106.

Laragione, R., Parise, M. \& S. Magni, 2008: The Pulo of Altamura. [in italian]- In: Parise, M., Inguscio, S. \& A. Marangella, (eds.) Geomorfologia carsica, Proc. $45^{\text {th }}$ Course CNSS-SSI, Grottaglie (Italy), pp. 129142.

Lauritzen, S.E. \& Y. Lundberg, 2000: Solutional and erosional morphology.- In Klimchouk A.B., Ford D.C, Palmer A.N. \& W. Dreybrodt, (eds.), Speleogenesis. Evolution of karst aquifers. National Speleological Society, Huntsville, Alabama, pp. 408-426.

Lollino, P., Parise, M. \& A. Reina, 2004: Numerical analysis of the behavior of a karst cave at CastellanaGrotte, Italy.- In: Konietzky, H., (ed.) Proc. $1^{\text {st }}$ Int. UDEC Symp. "Numerical modeling of discrete materials", Bochum (Germany), 29 Sept.-1 Oct. 2004, pp. 49-55. 
Lopez, N., Spizzico, V. \& M. Parise, 2009: Geomorphological, pedological, and hydrological characteristics of karst lakes at Conversano (Apulia, southern Italy) as a basis for environmental protection.- Environmental Geology, 58 (2), 327-337.

Mastronuzzi, G. \& P. Sansò, 2002: Pleistocene sea-level changes, sapping processes and development of valley networks in the Apulia region (southern Italy).Geomorphology, 46, 19-34.

Nash, D.J., 1996: Groundwater sapping and valley development in the Hackness Hills, Northern England.Earth Surface Processes and Landforms, 21 (9), 781-795.

Neboit, R., 1975: Plateaux et collines de Lucanie orientale et des Pouilles. Etude morphologique.- Libr. Honore Champion, p. 715, Paris.

North, L.A., van Beynen, P.E. \& M. Parise, 2009: Interregional comparison of karst disturbance: West-central Florida and southeast Italy.- J. Environ. Management, 90 (5), 1770-1781.

Palagiano, C., 1965: On the "lame" and "gravine" of Apulia. [in italian]- Ann. Fac. Econ. Comm., 21, 357-386.

Parise, M., 2003: Flood history in the karst environment of Castellana-Grotte (Apulia, southern Italy).Natural Hazards and Earth System Sciences, 3 (6), 593-604.

Parise, M., 2006: Geomorphology of the Canale di Pirro karst polje (Apulia, Southern Italy).- Zeitschrift für Geomorphologie N.F. 147, 143-158.

Parise, M., 2009: Lakes in the Apulian karst (Southern Italy): geology, karst morphology, and their role in the local history.- In: Miranda, F.R. \& L.M. Bernard, (eds.) Lake pollution research progress. Nova Science Publishers, Inc., New York, pp. 63-80.

Parise, M., 2010: The impacts of quarrying in the Apulian karst.- In: Carrasco, F., La Moreaux, J.W., Duran Valsero, J.J. \& B. Andreo (eds.) Advances in Research in Karst Media. Springer, pp. 441-447.

Parise, M. \& A. Reina, 2002: Geology of the Castellana Caves. [in italian]- Proceedings $3^{\text {rd }}$ Regional Congress of Speleology, Grotte e dintorni, 4, 221-230.

Parise, M. \& J. Gunn (eds.), 2007: Natural and anthropogenic hazards in karst areas: Recognition, Analysis and Mitigation.- Geological Society of London, Special Publications, 279.

Parise, M. \& M.A. Trisciuzzi, 2007: Geomechanical characterization of carbonate rock masses in underground karst systems: a case study from Castellana-Grotte (Italy).- In: Tyc, A. \& K. Stefaniak, (eds.) Karst and Cryokarst, Studies of the Faculty of Earth Sciences, University of Silesia, 45, pp. 227-236.
Parise, M., Proietto, G., Savino, G. \& M. Tartarelli, 2002: Reprisal of exploration activities at the Castellana Caves: first results and future perspectives. [in italian]- Proceedings $3^{\text {rd }}$ Regional Congress of Speleology, Grotte e dintorni, 4, 179-186.

Parise, M., Federico, A., Delle Rose, M. \& M. Sammarco, 2003: Karst terminology in Apulia (southern Italy).Acta Carsologica, 32 (2), 65-82.

Pasini, G., 2009: A terminology matter: paragenesis, antigravitative erosion or antigravitational erosion?.- International Journal of Speleology, 38 (2), 129-138.

Pieri, P., Festa, V., Moretti, M. \& M. Tropeano, 1997: Quaternary tectonic of the Murge area (Apulian foreland - Southern Italy).- Annali di Geofisica, 40 (5), 1395-1404.

Polemio, M., 2010: Extreme rainfall events and floods in a karstic environment (southern Italy).- Zeitschrift fur Geomorphologie, 54 (2), 195-219.

Renault P., 1968: Contribution a l'étude des actions mécaniques et sédimentologiques dans la spéléogenese.- Annales de Spéléologie, 23 (3), 530-596.

Ricchetti, G., Ciaranfi, N., Luperto Sinni, E., Mongelli, F. \& P. Pieri, 1988: Geodynamics and sedimentary and tectonic evolution of the Apulian Foreland. [in italian]- Memorie della Società Geologica Italiana, 41, 57-82.

Rudnicki, J., 1980: Karst in coastal areas - development of karst processes in the zone of mixing of fresh and saline water (with special reference to Apulia, Southern Italy).- Studia Geologica Polonica, 65, 9-59.

Sauro, U., 1991: A polygonal karst in Alte Murge (Puglia, Southern Italy).- Zeitschrift für Geomorphologie, $35,2,207-223$.

van Beynen, P.E., \& K.M. Townsend, 2005: A disturbance index for karst environments.- Environmental Management, 36, 101-116.

Williams, P.W., 2008: The role of the epikarst in karst and cave hydrogeology: a review.- International Journal of Speleology, 37, 1-10.

Zupan Hajna, N., 2003: Incomplete solution: weathering of cave walls and the production, transport and deposition of carbonate fines.- Carsologica, p. 167, Postojna-Ljubljana. 